\title{
The Value of Nasreddin Hodja Fikras in Terms of Turkish Teaching to Foreigners
}

\author{
M. Eyyüp SALLABAŞ*a ${ }^{*}$ Talha GÖKTENTÜRK ${ }^{\mathrm{b}}$
}

\begin{tabular}{l} 
Article Info \\
\hline DOI: $10.14686 /$ buefad.356300 \\
\hline Article History: \\
Received $\quad 20.11 .2017$ \\
Revised $\quad 15.01 .2018$ \\
Accepted $\quad 30.01 .2018$ \\
\hline Keywords: \\
Nasreddin Hodja, \\
Turkish Teaching to \\
Foreigners, \\
Fikra. \\
\hline ArticleType: \\
Research Article
\end{tabular}

\begin{abstract}
European Council Modern Languages Department that aims developing a common foreign language program, a common standard in foreign language teaching, common criterions and a tool that based on this, has forged The Common European Framework. Also Turkey, in the year of 2000, because of the Socrates program, adopted a language teaching according to this framework. Language teaching is also cultural education, with this side, combining culture elements that Turkish depends with language teaching is quite important. An important part of Turkish also forms literary texts. In these literary texts Nasreddin Hodja holds an important place and one of the important source that must use in language education process. In this study, potential value of Nasreddin Hodja jokes was revealed by document analysis method. Place of Nasreddin Hodja in the field of teaching Turkish to foreigners was examined and according to language levels that determined in European Language Portfolio, Nasreddin Hodja jokes was offered.
\end{abstract}

\section{Nasreddin Hoca Fıkralarının Yabancılara Türkçe Öğretimi Bakımından Değeri}

\begin{tabular}{l} 
MakaleBilgisi \\
\hline DOI: $10.14686 /$ buefad.356300 \\
\hline MakaleGeçmişi: \\
Geliş $\quad 20.11 .2017$ \\
Düzeltme $\quad 15.01 .2018$ \\
Kabul $\quad 30.01 .2018$ \\
\hline AnahtarKelimeler: \\
Nasreddin Hoca, yabanc1lara \\
Türkçe öğretimi, \\
F1kra. \\
\hline MakaleTürü: \\
Araştırma Makalesi \\
\end{tabular}

\begin{abstract}
Öz
Avrupa'da ortak bir yabancı dil öğretim programı ve yabancı dil öğretiminde ortak bir standart, ortak ölçütler ve buna dayalı bir araç geliștirmeyi amaçlayan Avrupa Konseyi Modern Diller Bölümü, Avrupa Dilleri Öğretimi Ortak Çerçeve Programı'nı oluşturmuştur. Bu çerçeve programına uygun olarak Avrupa Dil Portfolyosu geliştirilerek dil eğitiminde bir standart getirilmesi amaçlanmıştır. Türkiye de 2000 yılında üye olduğu Socrates Programı dolayısıyla bu çerçeveye göre dil öğretimini benimsemiştir. Dil öğretimi aynı zamanda kültür öğretimidir. Bu bakımdan yabancılara Türkçe öğretiminde Türk kültürünün de öğretilmesi esastır. Türk kültürünü ve mizah anlayışını yansıtan edebi metinler arasında yer alan Nasreddin Hoca fikraları dil öğretimi esnasında faydalanılması gereken edebî ürünlerin başlıcalarındandır. $\mathrm{Bu}$ çalışmada Nasreddin Hoca fikralarının yabancılara Türkçe öğretimindeki potansiyel değeri doküman analizi yöntemi ile ortaya konulmuştur. Türkçenin yabancı dil olarak öğretimi alanındaki ders materyallerinde Nasreddin Hoca fikralarının yeri incelenmiş ve Avrupa Dil Portfolyosu çerçevesinde belirlenmiş olan dil seviyelerine uygun olarak okutulabilecek örnek Nasreddin Hoca fikraları teklif edilmiştir.
\end{abstract}

\footnotetext{
*Corresponding Author: sallabas@ gmail.com

a Assoc. Prof. Dr., Yildiz Teknik University,

${ }^{\mathrm{b}}$ Res. Asst. Yildiz Teknik University,
} 


\section{Introduction}

The first sources we can trace to the history of the Turks are in Chinese texts. In the Chinese sources, for the first time, Turks were mentioned with their own names in the mid-6th century (Tekin-Ölmez, 2003: 12). The oldest traces belonging to the Turkish language date back to the Sumerians. Osman Nedim Tuna's studies on this subject revealed the data about the use of Turkish words in Sumerian (Tuna, 1990: 57). The first written work that is about teaching Turkishas a foreign language in the historical process of Turkish language is the Divânü Lügâti 't-Türk that was worked by Kâşgarlı Mahmud. The works started with Divânü Lügâti 't-Türk and Kitâbu Cevâhirü 'n-Nahv fi Lügâti 't-Türk were continued by the works given in Mamluk, Kıpçak, Chagatai and Anatolia.

It is seen that these works put forward during the historical periods of Turkish that contains elements of Turkish culture. Researches that is attracting attention to this issue, sought to establish various definitions of language and cultural relations. Ergin is identified the language as "A natural means of negotiating between people is defined as a living entity that has its own laws and only develops within the framework of these laws, a system of secret agreements laid down on the basis of unknown times, a social institution built of voices"(2012: 3). With this definition, it seems that language has emerged through language structures that have been reconciled by each individual who constitutes the society. In this respect, it is seen that the language is closely connected to the nation, the dignity, the past, the language which is transferred from the beginning to the end, and the individual brings to the state of the chain between the past and the future (Doğan, 2007: 13).

In this way, culture is one of the elements that is transferred from people to people by the persons who is serving as a circle. In the Turkish dictionary (TDK, 2011: 1558 ), culture is identified as "all of the material and spiritual values created in the historical, social development process and the means of showing the extent of the sovereignty of man in his natural and social environment". People think with concepts and tell them what they think with language indicators (Kiran, 2010: 60). The formation of the cultures and the transmission of the generations by the generations is possible only through the conveyance of the concepts from the speakers.

In this way, the Turks have formed different cultural elements throughout their history and they have come to the future by protecting these elements for generations. The acceptance of Islam by the Turks and the process of developing into Anatolia has laid the foundation for the emergence of new cultural elements. Nasreddin Hodja also took his place on the history screen in this period.

Nasreddin Hodja, one of the main humour heroes of Turkish culture, was born in $605[=1208]$ in the village of Hortu in Sivrihisar. After his father, who was a village imam, passed away, he took over this responsibility himself. Then he went to Akşehir and served as a clergyman and probably died in 683 [= 1284](Albayrak, 2006: 418 ).

Nasreddin Hodja, one of the humour symbols of the Muslim Turkish people, seems to cover a wide geographical area including Thailand, Punjab, Turkestan, Germany, France, England, Iberian Peninsula, Baltic States, Scandinavia, North Africa, Egypt and Sudan. Although some of these similarities can be explained by chance, they should not be forgotten(Albayrak, 2006: 419a).

In addition to subject similarities, the presence of characters similar to Nasreddin Hodja in different cultures is striking. The Cuhâs of the Arabs, Till Eulengspiegel of the Germans, Paul Bunyan of the Americans, Hetar Petar of the Bulgarians, Joe Miller of the English, Bertoldo of the Italians, Balakirew of the Russians, Kerempuh and Era of the Yugoslavians, Hodja has quite similar chapters(Albayrak, 2006: $\left.419^{\mathrm{a}}\right)$.

It can be seen that Nasreddin Hodja fikras contain two parts in terms of structure. In the first part, a small case is explained and the places and persons where the events occurred are mentioned. Since people are not usually featured in historical characters, the elements of the place and person are more and more alive day by day. In the second part, Nasreddin Hodja gives a statement or a statement of what he says according to the circumstances. In such parts the Hodja reveals the truth in his passage by revealing a truth which seems to be opposite to reality(Tecer, 1964: $110^{\mathrm{b}}$ ). 
Each language is used in different contexts based on the culture it depends on in the society it is spoken to. Culture is also one of the most important factors in the formation of language specific contexts. The person who learns a foreign language is included in a new culture world together with the culture he learns in this regard. For this reason, teaching Turkish as a foreign language should be an environment where Turkish culture is described and reflected(Pehlivan, 2007: 1).

It seems that Nasreddin Hodja's fikras has been studied for its place and availability in language teaching. Demirtaş (2012: 97) stated that Nasreddin Hodja is a literary product that can be used in value education because he has many different values belonging to different fields.

It is stated in the study by Baki and Karakuş (2014) that fikrascan be used in the course books in the main language teaching; because of it is importance for the improving language skills and the transferring culture thanks to the rich contents they have. Yalçın (2009) found that there was a meaningful difference between the experiment group in which the word education was performed by anecdotes and the control group in which the word education was done by traditional methods. According to results, experiment group has been showed significantly more progress than then the control group.

In the study that was made by Şen (2016) document analysis method has been used. As a result of the findings, it was suggested that Nasreddin Hodja fikras could be used in the development of basic language skills and in the process of value education. Similarly, in the research conducted by Karakaya (2007), it is stated that if they are not based on imposition, Nasreddin Hodja fikras will be useful in moral education when they are provided according to the levels of students.

In order to determine the frequency of Nasreddin Hodja fikras in the course books of teaching Turkish as the main language, in the study that was made by Ulutaş and Kara (2017), it was stated that increasing the texts about Nasreddin Hodja in the textbooks, to give place to different Nasreddin Hodja fikras, giving these texts according to student's level, and selected texts must have a role for transferring cultural values. The results support the study conducted by Tekşan (2012), in order to determine the level of use of Nasreddin Hodja's fikras in terms of Turkish language courses. It has been stated that it is necessary to increase the place of Nasreddin Hodja fikras in the field of Turkish lessons.

Nasreddin Hodja fikras could be help to contribute to the development of creative thinking skills. It has been suggested that Nasreddin Hodja should be included to course books according to the study that was made by Temizkan (2011) in order to develop students' creative thinking skills in Turkish lessons.

When the studies about Nasreddin Hodja fikras in Turkish teaching as a foreign language examined, it has been seen Akkaya (2013) stated that language structures that is using in Nasreddin Hodja fikras are combined with cultural elements. For this reason, it is stated that Nasreddin Hodja texts may be useful for students' learning Turkish as a foreign language at the level of B2 and C1 on the basis of findings of the research.

In the study conducted by Doğru and Kaplan (2017), the Istanbul Turkish teaching set was examined and the elements of folk literature in the study group were found inadequate to be used in place. One of the important elements of Turkish folk literature is Nasreddin Hodja Fikras. Nasreddin Hodja will be able to contribute to the development of language skills and culture transfer by determining the location of fikras in course books. Taking the texts of Nasreddin Hodja in to the course books in accordance with the level of students learning Turkish as a foreign language can be helpful in this process.

Taking these points into consideration, the first place in the study was the question of the place of Nasreddin Hodja, one of the important texts of Turkish culture, in foreign language teaching of foreigners. Then, a sample Nasreddin Hodja texts, which can be read in accordance with the language levels determined in the framework of the European Language Portfolio and the linguistic information set for these levels, have been proposed. 


\section{Method}

The research model used in the research aiming to determine the existence area of Nasreddin Hodja subjects in the sets used in the teaching process of Turkic languages as a foreign language and the research method used in obtaining the data in this model, the study group, the process of gathering the data and the analysis process of the data are explained.

\section{Aim of The Study}

In this study determining the existence of the Nasreddin Hodja fikras in the widely used Turkish teaching sets and according to levels determining the places of fikras was aimed. Thoroughly for teaching Turkish as a foreign language area, determining the suitable Nasreddin Hodja fikras according to language levels in European Language Portfolio has been aimed.

\section{Research Design}

In this study, case study was preferred from qualitative research models. According to Yin (2009), case study is a model used in social sciences research and is a research model that is used when a phenomenon is not evident by the exact lines of the boundary between the phenomenon and the environment in which it operates, and where there is more than one evidence or data source.

Document analysis was used in qualitative research methods in the collection of data in the study. Document analysis covers the examination of written materials containing information about the cases or phenomena targeted for investigation. Traditionally, document analysis is known as a method used by historians, anthropologists, and linguists (Yıldırım\& Şimşek, 2006: 187).

\section{Study Group}

The study was designed to examine the degree of inclusion of Nasreddin Hodja faculty in the teaching sets used in teaching Turkish to foreigners. The study group of the researchers created Gazi University TÖMER, Istanbul, Hitit and Yedi İklim Turkish teaching sets, which were prepared for the Turkish teaching of foreigners and widely used in Turkey. Careful attention has been paid to the widespread use of the sets that make up the working group to provide in-depth information in the research and to ensure the formation of a rich data pool, and therefore the purposeful sampling method has been preferred. Objective sampling is a sampling method that is used to determine the presence of rich sources of information, particularly when in-depth research is desired. It is possible to reach a rich pool of information by conducting an indepth examination of the cases studied in the selected samples (Patton, 2002: 46; Yıldırım \& Şimşek, 2016: 118).

\section{Data Collection}

In the process of gathering the data, the Turkish teaching set was examined as four foreign languages taken as a sample set by the researchers and the obtained data were tabulated and given in the findings.

\section{Data Analysis}

In the direction of the data obtained by the analysis of the document, the distribution of Nasreddin Hodja faculties according to their level in Turkish teaching sets as foreign language is given as number values. Subsequently, according to each level from level A1 to level C1, the findings of Nasreddin Hodja were presented in the light of the opinion of 3 experts and the findings were completed.

\section{Findings}

\section{Findings on the Placement of Nasreddin Hodja Disciples in Turkish Teaching Sets for Foreigners}

In this section, it was tried to determine the presence of Nasreddin Hodja fikras in Turkish teaching sets used extensively in Turkey. For this purpose, the levels of A1, A2, B1, B2, C1 and C2 of Gazi University TÖMER, Istanbul, Hitit and Seven Climate Turkish teaching sets were examined. The results are as follows: 
Table 1. Placement of Nasreddin Hodja Disciples in Turkish Teaching Sets for Foreigners

\begin{tabular}{lcccc}
\hline $\begin{array}{l}\text { Level } \\
\text { Informations }\end{array}$ & $\begin{array}{c}\text { Gazi } \\
\text { TÖMER }\end{array}$ & İstanbul & Hitit & YediİklimTürkçe \\
\hline A1 & - & - & - & - \\
A2 & - & $+(2$ fikras $)$ & - & $+(1$ fikras $)$ \\
B1 & - & - & - & - \\
B2 & - & $+(1$ fikras $)$ & - & $+(2$ fikras $)$ \\
C1 & - & $+(4$ fikras $)$ & - & $+(1$ fikras $)$ \\
C2 & - & - & - & - \\
\hline
\end{tabular}

It is seen that in the tablet hat can be seen in above, Gazi TÖMER and Hitit teaching sets did not include Nasreddin Hodja fikras. While the Istanbul teaching set did not include Nasreddin teacher teachers at A1 and B1 levels; in the course books, 2 fikras at level A2(s. 55, Rüya; s. 60, Eşeğin Sözü), 1 fikras at level B2(s. 70, Ye Kürküm Ye), and 3 fikras at level C1 in workbooks(s. 74, Yemeğin Buğusuna Akçenin Sesi, Peştamal; s. 75, Nasreddin Hoca ve Eşyaları). In the Yedi İklim Turkish teaching set prepared by the Yunus Emre Institute, Nasreddin Hodja fikras were not included in A1, B1 and C2 levels. In the work books, there were 1 fikra at A2 level (s. 113, Mektup), 1 fikra at B2 level (s. 49, Kazan Doğurdu) and 1 fikra at C1 level (s. 132, Hocanın Hesab1). In the work books, it has been determined 1 fikra at B2 level (s. 50, Hindi).

\section{Nasreddin Hodja Fikras’ Proposals According to Level}

\section{A1 Fikra}

Bir gün Nasreddin Hoca, evin içinde yüzüğünü yitirdi. Yüzüğü aradı ama yoktu. Evin önüne çıktı. Orada da aradı. Komşuları Hoca'yı gördü ve sordular:

Komşu: Hocam, orada ne arıyorsun?

Hoca: Yüzüğümü.

Komşu: Sen yüzüğü nerede kaybettin?

Hoca: Evde.

Komşu: Evdeki yüzüğü niçin dışarıda arıyorsun?

Hoca: Ev çok karanlık (Güleç, 2012: 78-79).

\section{A2 Fikra}

\section{Dünyanın Merkezi}

Nasreddin Hoca'nın arkadaşları bir gün ona sormuşlar:

- Hocam dünyanın merkezi neresidir?

Hoca:

- Ayağının altına bakmış. Burası dünyanın merkezidir.

Arkadaşları gülmüşler ve:

- Hocam nereden biliyorsun?

Hoca:

- Buyurun, ölçebilirsiniz (Koltaş 2014: 13). 


\section{B1 Fikra}

\section{Sen de Haklısın}

Nasreddin Hoca kadı iken bir gün dostlarından biri evine gelmiş, bir komşusuna karşı açtığı bir davayı anlatarak:

- "Hoca! Ne dersin, haklı miyım?" diye sormuş.

Hoca şöyle bir düşünüp:

- "Haklısın." demiş.

Ertesi gün dostunun dava ettiği komşusu da Hoca’ya uğrayıp aynı davayı kendi açısından anlatarak:

- "Hoca! Ne dersin, haklı mıyım?" diye sormuş.

Hoca şöyle bir düşündükten sonra ona da:

- Haklısın, demiş.

Kocasının konuşmalarını kapı arasından dinleyen karısı, adam gittikten sonra:

- Hoca, dün davacı geldi, adama haklısın dedin. Bugün davalı geldi, ona da haklısın dedin. Hem davacı hem de davalı ikisi birden haklı olur mu?

Hoca şöyle bir düşündükten sonra cevap vermiş:

- Sen de haklısın hanım (Güleç, 2012: 23)!

\section{B2 Fikra}

\section{Yorgan Gitti Kavga Bitti}

Gecenin bir yarısında Hoca'nın evinin önünde iki kişi kavgaya tutuşunca Hoca meraklanmış. Karısının itirazını dinlememiş, dışarı çıkmış. Üstüne de dışarıda üşümemek için yorganını almış.

Adamlara:

-"Yahu durun, neden kavga ediyorsunuz?" demeye firsat kalmadan biri Hoca'nın sırtındaki yorganı kaptı̆̆ gibi kaçmış. Öteki de başka bir yöne sıvışmış. Hoca eve eli boş dönmüş. Karısı sormuş:

- Hocam kavgayı ayırabildin mi?

Hoca:

- Tabii ki hanım, demiş. Yorgan gitti, kavga bitti (Koltaş, 2014: 49)

\section{C1 Fikra}

\section{Ye Kürküm Ye}

Günlerden bir gün Hoca'yı yemeğe davet etmişler. Hoca davete, günlük kıyafetiyle katılmış. Katılmış ama ne hoş geldin, ne sefa getirdin diyen var. Herkes, alı pullu kıyafetlilere el pençe divan duruyormuş. Bakmış olacak gibi değil Hoca, bir koşu evine gitmiş, sandıktaki işlemeli kürkünü giyip yemeğe geri dönmüsş. Biraz önce hoş geldin demeyenler, önünde yerlere kadar eğilmişler. Hoca'yı, yere göğe sığdıramayıp başköşeye oturtmuşlar. Kuzunun en güzel yerini önüne koymuşlar. Herkes hocanın yemeğe başlamasını bekliyormuş. Hoca bir taraftan kürkünün kolunu sofrada sallamaya, bir taraftan da "Ye kürküm ye, ye kürküm ye!" demeye başlamış.

-İlahi Hoca, demişler, kürkün yemek yediğini kim görmüş? Hoca taşı gediğine koymakta gecikmemiş:

-Eee, demiş Hoca, marifet kürkteymiş, kürksüz adamdan sayılmadık... İtibarı o gördü, yemeği de o yesin (Koltaş, 2014: 48) 


\section{Discussion and Conclusion}

It is stated that studies on the development of language skills and use of places and texts in the textbooks of Turkish cultures and studies on the transfer of culture have proved that the cultural products coming from folk literature are inadequate in the textbooks and that studies to improve language skills through phrasal may be more beneficial. Besides, it is stated that Nasreddin Hodja students can contribute to the development of the active vocabulary and creative thinking skills of the students who learn Turkish as a foreign language in terms of richness of language elements and elements of Turkish culture. It can be seen that Nasreddin Hodja folklore can be used in the process of culture transfer in terms of richness in terms of Turkish cultural elements. In this study, it was tried to determine whether the Nasreddin Hodja faculty participates in foreign language teaching sets used widely in Turkey, and the level of the places where they are located(Akkaya, 2013; Baki \& Karakuş, 2014; Demirtaş, 2012; Doğru \& Kaplan, 2017; Karakaya, 2016; Şen, 2007; Tekşan, 2012; Temizkan, 2011; Ulutaş \& Kara, 2017; Yalçın, 2009).

As a result of the research, it was seen that Nasreddin Hodja fikras were never found in Gazi TÖMER and Hitit Turkish teaching sets. Istanbul Turkish teaching set; A2, B2, and C1 levels.

In the Yedi İklim Turkish teaching set prepared by the Yunus Emre Institute, Nasreddin Hodja fliers were not included in the A1, B1 and C2 levels, whereas 4 levels were given in A2, B2 and C1 levels.

According to these results, it can be said that the Seven Climate Turkish and Istanbul sets contributed to the introduction of Nasreddin Hodja factions as foreigners and thus to the transmission of Turkish culture.

It is possible to say that Nasreddin Hodja faculty was not systematically used in Turkish teaching sets as a foreign language and that Nasreddin Hodja had a small number of places. The fact that Turkish language teaching as a foreign language is a new field and that there is not enough studies to design textbooks for this reason can be considered as one of the reasons for the result. As a matter of fact, the results obtained are parallel to the study and overlap with the previous studies revealed by literature review.

On the other hand, according to European language portfolio, for every level of language learning Nasreddin Hodja fikras have also been proposed.

From the study results it is possible to bring the following proposal:

1. Language teaching is the teaching of cultures taught at the same time. Turkish culture should be given weight in Turkish teaching sets prepared for foreigners.

2. Nasreddin Hodja is one of the main elements of understanding of Turkish culture and humour and has influenced the culture of many nations. Nasreddin Hodja, a member of the common culture, should be involved in the teaching of Turkish language to foreigners in line with the principle of "learning from known to unknown".

3. Nasreddin Hodja must be used at every exchange rate in terms of the simplicity of his edits and the fact that language structures can be edited.

\section{Acknowledgments}

The work was presented as an oral paper at the International Nasreddin Hodja Symposium held in Eskişehirbetween September 30 - October 2, 2016. 


\title{
Nasreddin Hoca Fıkralarının Yabancılara Türkçe Öğretimi Bakımından Değeri
}

\author{
Giriş
}

Türklerin tarih sahnesine çıkışını takip edebildiğimiz ilk kaynaklar Çin metinlerindedir. Çin kaynaklarında Türkler kendi adları ile ilk kez VI. yüzyıl ortalarında anılırlar (Tekin-Ölmez, 2003: 12). Türk diline ait en eski izler ise Sümerlere kadar dayanmaktadır. Osman Nedim Tuna'nın bu konuda yaptığı çalışmalar Türkçe kelimelerin Sümercede de kullanıldığına yönelik veriler ortaya koymuştur (Tuna, 1990: 57). Tarihi süreçte gelişmeye devam eden Türkçenin yabancı dil öğretimi ile ilgili bilinen ilk yazılı eser Kaşgarlı Mahmud'un Divânü Lügâti 't-Türk isimli eseridir. Divânü Lügâti 't-Türk ve Kitâbu Cevâhirü ' $n$ Nahv fi Lügâti 't-Türk isimli eserlerle başlayan çalışmalar Memluk, Kıpçak, Çağatay ve Anadolu sahasında verilen eserlerle devam etmiştir.

Türkçenin tarihî dönemleri içinde ortaya konan bu eserlerin Türk kültürünü de içinde barındıran unsurlar taşıdığı görülmektedir. Bu hususa dikkat çeken araştırmacılar dil-külttür ilişkisi üzerine çeşitli tarifler ortaya koymaya çalışmışlardır. Ergin (2012: 3) dili "İnsanlar arasında anlaşmayı sağlayan tabii bir vasıta kendisine mahsus kanunları olan ve ancak bu kanunlar çerçevesinde gelişen canlı bir varlık, temeli bilinmeyen zamanlarda atılmış bir gizli antlaşmalar sistemi, seslerden örülmüş içtimaî bir müessese" olarak tarif etmektedir. Bu tariften hareketle dilin toplumu oluşturan her bir kimse üzerinde uzlaştığı dil yapıları sayesinde ortaya çıktığı söylenebilmektedir. Bu bakımdan dilin insanları ulusuna, yurduna, geçmişine sıkı sıkıya bağladığı, kuşaktan kuşağa aktarılarak gelen dilin insanları geçmişle gelecek arasındaki zincirin bir halkası durumuna getirdiği görülmektedir. (Aksan, 2007: 13).

Bu yolla halka vazifesi gören insanlığın kuşaktan kuşağa aktardığı unsurlardan birini de kültür oluşturmaktadır. Kültür Türkçe sözlükte (TDK 2011: 1558) "Tarihsel, toplumsal gelişme süreci içinde yaratılan bütün maddi ve manevi değerler ile bunları yaratmada, sonraki nesillere iletmede kullanılan, insanın doğal ve toplumsal çevresine egemenliğinin ölçüsünü gösteren araçların bütünü, hars, ekin" olarak tanımlanmıştır. İnsanlar kavramlarla düşünür ve düşündüklerini de dil göstergeleri ile anlatır (Kıran, 2010: 60). Kültürün oluşması ve nesilden nesile aktarımı da ancak kavramların göstergelerle konuşucudan muhataba aktarımı ile mümkündür.

İşte bu vesileyle Türkler tarihleri boyunca farklı kültür unsurları oluşturmuşlar ve bu unsurları nesiller boyunca koruyarak geleceğe taşımışlardır. Türklerin İslam'ı kabulü ve Anadolu'ya gelişi ile gelişen süreç yeni kültür unsurlarının doğmasına zemin hazırlamıştır. Nasreddin Hoca da bu dönemde tarih sahnesindeki yerini almıştır.

Türk kültürünün başlıca mizah kahramanlarından biri olan Nasreddin Hoca, Sivrihisar'ın Hortu köyünde 605 [=1208] yılında doğmuştur. Köyün imamı olan babası vefat ettikten sonra bu vazifeyi kendisi devralmıştır. Ardından Akşehir'e giderek kadılık vazifesi yürütmüş ve muhtemelen 683 [=1284] yılında vefat etmiştir (Albayrak, 2006: 418 ).

Müslüman Türk halkının mizah sembollerinden olan Nasreddin Hoca'nın fikralarında yer alan konuların Tayland, Pencap, Türkistan, Almanya, Fransa, İngiltere, İber Yarımadası, Baltık ülkeleri, İskandinavya, Kuzey Afrika, Mısır ve Sudan dâhil geniş bir coğrafyayı ihtiva ettiği görülmektedir. Bu benzerliklerin bir kısmı tesadüfle açıklanabilirse de aynı kaynaktan gelmiş olma ihtimalleri de unutulmamalıdır (Albayrak, 2006: 419 a).

Konu benzerliklerinin yanında farklı kültürlerde Nasreddin Hoca’ya benzer karakterlerin varlığı dikkat çekicidir. Arapların Cuhâ'sı, Almanların Till Eulengspiegel'i, Amerikalıların Paul Bunyan'1, Bulgarların Hitar Petar'1, İngilizlerin Joe Miller'i, İtalyanların Bertoldo'su, Rusların Balakirew'i, Yugoslavların Kerempuh ve Era'sı, Japonların Ikkyu'sunun Hoca ile oldukça benzer fikraları vardır (Albayrak, 2006: $\left.419^{\mathrm{a}}\right)$.

Nasreddin Hoca fikraları incelendiğinde yapı bakımından iki kısımdan oluştuğu görülmektedir. Birinci kısımda küçük bir vaka anlatılırken hadisenin geçtiği yer ve kişiler belirtilir. Kişilerde tarihi karakterlere çoklukla yer verilmediğinden yer ve kişi unsurları daha ziyade günlük hayattandır. İkinci kısımda ise Nasreddin Hocanın şartların lüzumuna göre söylediği bir söz ya da tespitlerini sunduğu bir durum söz 
konusudur. Bu kısımlarda Hoca gerçeğe zıt gibi görünen bir hakikati ortaya koyarak fikrasındaki hikmeti izah eder (Tecer, 1964: 110 ${ }^{\mathrm{b}}$ ).

Her dil konuşulduğu toplum içinde bağlı bulunduğu kültüre dayalı olarak farklı meyanlarda kullanılır. Bir dilin kendisine has meyanların oluşmasında en mühim faktörlerden biri de kültürdür. Yabancı dil öğrenen kişi bu bakımdan öğrendiği kültürle beraber yeni bir kültür dünyasına dâhil olmaktadır. Bu sebeple yabanc1 dil olarak Türkçe öğretimi de Türk kültürünün anlatıldığı, yansıtıldığı bir ortam olmalıdır (Pehlivan, 2007: 1).

Nasreddin Hoca fikralarının dil eğitimindeki yeri ve kullanılabilir olma derecesine yönelik olarak yapılan çok sayıda çalışma olduğu görülmektedir. Demirtaş (2012: 97) tarafından yapılan çalışmada Nasreddin Hoca fikralarının içinde bulundurdukları farklı alanlara ait çok farklı değer unsurları barındırması sebebiyle değerler eğitiminde kullanılabilecek edebi ürünlerden olduğu belirtilmiştir.

Fıkraların ana dili öğretiminde kullanılan ders kitaplarındaki yerine yönelik Baki ve Karakuş (2014) tarafından yapılan çalışmada fikraların sahip oldukları zengin içerik sebebiyle ders kitaplarında kullanılmasının dil becerilerinin geliştirilmesi ve kültür aktarımı bakımından mühim olduğu belirtilmektedir. Yalçın (2009) tarafından kelime öğretiminde fikraların kullanılması üzerine deneyli desenle tasarladığı araştırmasında fikralarla kelime öğretiminin yapıldığı deney grubu ile gelenekli kelime öğretimi yapılan kontrol grubu arasında deney grubu lehine anlamlı bir fark bulmuş ve fikralarla yapılacak kelime öğretiminin öğrencilerin aktif söz varlığını geliştiren bir yol olacağı araştırmada belirtilmiştir.

Nasreddin Hoca fikralarına yönelik olarak Şen (2016) tarafından yapılan araştırmada doküman incelemesi kullanılmıştır. Elde edilen bulgular neticesinde Nasreddin Hoca fikralarının temel dil becerilerinin geliştirilmesinde ve değerler eğitimi sürecinde kullanılabileceği teklifinde bulunulmuştur. Benzer şekilde Karakaya (2007) tarafından yapılan araştırmada empoze etme üzerine kurulu olmadığından seviyelere uygun olarak verilmesi hâlinde Nasreddin Hoca fikralarının moral eğitimde yararlı olacağı belirtilmektedir.

Nasreddin Hoca fikralarının ana dili olarak Türkçe öğretimi sürecinde kullanılan ders kitaplarındaki sıklığını belirlemek için Ulutaş ve Kara (2017) tarafından yapılan çalışmada ders kitaplarında Nasreddin Hoca ile ilgili metinlerin artırılması, herkesçe bilinmeyen farklı Nasreddin Hoca fikralarına yer verilmesi, öğrencilerin sınıf düzeyinde seviyelerine uygun Nasreddin Hoca fikralarının oluşturulması ve ders kitapları için seçilen fikraların kültürel değerleri aktarma rolünü üstlenen bir yapıda olması gerektiği belirtilmiştir. Sonuçlar Tekşan (2012) tarafından Türkçe dersi alanları açısından Nasreddin Hoca fikralarının ne derecede kullanılabilir olduğunu belirlemek amacıyla yapılan çalışmayı desteklemektedir. Araştırmada Türkçe dersi öğrenme alanlarında Nasreddin Hoca fikralarının yerinin artırılmasının zaruri olduğu belirtilmiştir.

Nasreddin Hoca fikralarının yaratıcı düşünme becerilerinin geliştirilmesi noktasında katkı sağlayıp sağlayamayacağı hakkında Temizkan (2011) tarafından yapılan çalışmada Türkçe derslerinde öğrencilerin yaratıcı düşünme becerilerinin geliştirilmesi için Nasreddin Hoca fikralarına yer verilmesi gerektiği ortaya konulmuştur.

Nasreddin Hoca fikralarının yabancı dil olarak Türkçe öğretiminde kullanılmasına yönelik çalışmalara bakıldığında Akkaya (2013) Nasreddin Hoca fikralarında kullanılan dil yapılarının kültürel unsurlarla birleşmiş bir hâlde olduğunu belirtmiştir. $\mathrm{Bu}$ sebeple araştırmanın bulgularından hareketle $\mathrm{B} 2$ ve $\mathrm{C} 1$ seviyesinde yabancı dil olarak Türkçe öğrenen öğrenciler için Nasreddin Hoca metinlerinin faydalı olabileceği belirtilmiştir.

Doğru ve Kaplan (2017) tarafından yapılan çalışmada İstanbul Türkçe öğretim seti incelenmiş ve çalışma grubunda halk edebiyatı unsurları yerinde kullanılmakla beraber yetersiz bulunmuştur. Türk halk edebiyatının mühim unsurlarından biri de Nasreddin Hoca fikralarıdır. Nasreddin Hoca fikralarının ders kitaplarındaki yerinin belirlenmesi ve yabancı dil olarak Türkçe öğrenen öğrencilerin seviyelerine uygun olarak Nasreddin Hoca metinlerinin ders kitaplarında yerini alması dil becerilerinin geliştirilmesi ve kültür aktarımı hususunda katkı sağlayabilecektir.

Bu hususlar dikkate alınarak çalışmada ilk olarak, Türk kültürünün mühim metinlerinden biri olan Nasreddin Hoca fıkralarının yabancılara Türkçe öğretimindeki yeri sorgulanmıştır. Ardından Avrupa Dil 
Portfolyosu çerçevesinde belirlenmiş olan dil seviyelerine ve bu seviyeler için belirlenen dil bilgisi yapılarına uygun olarak okutulabilecek örnek Nasreddin Hoca fikraları teklif edilmiştir.

\section{Yöntem}

Yabancı dil olarak Türkçenin öğretimi sürecinde kullanılan setlerde Nasreddin Hoca fikralarının varlık alanının belirlenerek incelenmesinin amaçlandığı araştırmada kullanılan araştırma modeli ve bu model dairesinde verilerin elde edilmesinde kullanılan araştırma metodu, çalışma grubu, verilerin toplanma süreci ve verilerin analiz süreci verilen başlıklar bünyesinde izah edilmiştir.

\section{Araştırmanın Amacı}

Yapılan çalışmada Nasreddin Hoca fikralarının Türkiye'de yaygın olarak kullanılan yabancılara Türkçe öğretim setlerinde yer alıp almadı̆̆ı, yer alanların hangi kur seviyelerinde bulundukları tespit edilmeye çalışılmıştır. Bu doğrultuda A1 seviyesinden $\mathrm{C} 1$ seviyesine yabancı dil olarak Türkçe öğrenen öğrencilerin seviyelerine uygun Nasreddin Hoca fikralarının belirlenmesi amaçlanmıştır.

\section{Araştırma Modeli}

Bu araştırmada nitel araştırma modellerinden vaka çalışması tercih edilmiştir. Yin'e (2009) göre vaka çalışması sosyal bilimler araştırmalarında kullanılan bir modeldir ve bir fenomeni kendi gerçek hayat çerçevesinde çalışan, fenomen ve içinde bulunduğu çevre arasındaki sınırların kesin hatlarıyla belirgin olmadığı ve birden fazla kanıt veya veri kaynağının mevcut olduğu durumlarda kullanılan bir araştırma modelidir.

Araştırmada verilerin toplanmasında nitel araştırma metotlarındandoküman analizi kullanılmıştır. Doküman analizi, araştırılması hedeflenen fenomen veya fenomenler hakkında bilgi içeren yazılı materyallerin incelenmesini kapsar. Gelenekli olarak doküman analizi, tarihçilerin, antropologların ve dil bilimcilerin kullandığı bir yöntem olarak bilinir (Yıldırım ve Şimşek, 2006: 187).

\section{Çalışma Grubu}

Çalışma yabancılara Türkçe öğretiminde kullanılan öğretim setlerinin Nasreddin Hoca fikralarını ihtiva etme derecesini incelemek amacıyla oluşturulmuştur. Araştırmanın çalışma grubunu yabancılara Türkçe öğretimi için hazırlanan ve Türkiye'de yaygın olarak kullanılan ders materyallerinden Gazi Üniversitesi TÖMER, İstanbul, Hitit ve Yedi İklim Türkçe öğretim setleri oluşturmuştur.

Tablo 1. Çalışma Grubu Kapsamında İncelenen Setler

\begin{tabular}{lcccc}
\hline $\begin{array}{l}\text { İncelenen } \\
\text { Öğretim } \\
\text { Setlerinin } \\
\text { Seviyeleri }\end{array}$ & $\begin{array}{c}\text { Gazi } \\
\text { TÖMER }\end{array}$ & İstanbul & Yeni Hitit & Yedi İklim Türkçe \\
\hline A1 & + & + & + & + \\
A2 & + & + & + & + \\
B1 & + & + & + & + \\
B2 & + & + & + & + \\
C1 & + & + & + & + \\
C2 & + & + & + & + \\
\hline
\end{tabular}

Araştırmada derinlemesine bilgi elde etmek ve zengin bir veri havuzunun oluşmasını sağlamak için çalışma grubunu oluşturan setlerin yaygın olarak kullanılmasına dikkat edilmiş ve bu sebeple amaçlı örnekleme metodu tercih edilmiştir. Amaçlı örnekleme bilhassa derinlemesine araştırmanın yapılmak istendiği zengin bilgi kaynaklarının mevcudiyetinin tespit edilmesi hâlinde kullanılan bir örnekleme metodudur. Bu metotla seçilen örneklemelerde çalışılan vaka hususunda derinlemesine inceleme yaparak zengin bir bilgi havuzuna ulaşmak mümkün olmaktadır (Patton, 2002: 46; Yıldırım ve Şimşek 2016: 118). 


\section{Verilerin Toplanması}

Verilerin toplanması sürecinde araştırmacılar tarafından örnek set olarak alınan dört adet yabancı dil olarak Türkçe öğretim seti tetkik edilmiş ve elde edilen veriler tablolaştırılarak bulgular kısmında verilmiştir.

\section{Verilerin Analizi}

Doküman analizi ile elde edilen veriler doğrultusunda Nasreddin Hoca fikralarının yabancı dil olarak Türkçe öğretim setlerinde seviyelere göre dağılımı sayılı değerler şeklinde verilmiştir. Akabinde A1 seviyesinden C1 seviyesine kadar her seviyeye uygun olarak Nasreddin Hoca fikraları sunularak bulgular kısmı tamamlanmıştır.

\section{Bulgular}

Yabancılara Türkçe Öğretim Setlerinde Nasreddin Hoca Fıkralarına Yer Verilmesine İlişkin Bulgular

Bu kısımda Türkiye'de yaygın olarak kullanılan yabancılara Türkçe öğretim setlerinde Nasreddin Hoca fikralarının mevcudiyeti belirlenmeye çalışılmıştır. Bu amaçla Gazi Üniversitesi TÖMER, İstanbul, Hitit ve Yedi İklim Türkçe öğretim setlerinin A1, A2, B1, B2, C1 ve C2 seviyeleri incelenmiştir. Ulaşılan sonuçlar aşağıdaki tabloda verilmiştir:

Tablo 2. Yabancılara Türkçe Öğretim Setlerinde Nasreddin Hoca Fıkralarına Yer Verilme Durumu

\begin{tabular}{lcccc}
\hline $\begin{array}{l}\text { Kur } \\
\text { Bilgileri }\end{array}$ & $\begin{array}{c}\text { Gazi } \\
\text { TÖMER }\end{array}$ & İstanbul & Hitit & Yedi İklim Türkçe \\
\hline A1 & - & - & - & - \\
A2 & - & $+(2$ fikra $)$ & - & $+(1 \mathrm{fikra})$ \\
B1 & - & - & - & - \\
B2 & - & $+(1 \mathrm{fikra})$ & - & $+(2 \mathrm{fikra})$ \\
C1 & - & $+(4 \mathrm{fikra})$ & - & $+(1 \mathrm{fikra})$ \\
C2 & - & - & - & - \\
\hline
\end{tabular}

Yukarıdaki tabloda Gazi TÖMER ve Hitit öğretim setlerinde Nasreddin Hoca fikralarına yer verilmediği görülmektedir. İstanbul öğretim seti Nasreddin Hoca fikralarına A1 ve B1 seviyelerinde yer vermezken; ders kitaplarında A2 seviyesinde 2 fikra (s. 55, Rüya; s. 60, Eşeğin Sözü), B2 seviyesinde 1 fikraya (s. 70, Ye Kürküm Ye); çalışma kitaplarında C1 seviyesinde 4 fikraya (s. 74, Yemeğin Buğusuna Akçenin Sesi;s. 74 Peştamal; s. 75, Nasreddin Hoca ve Eşyaları; s. 147 Pazarlık) yer vermiştir.

Yunus Emre Enstitüsü tarafından hazırlanan Yedi İklim Türkçe öğretim setinde Nasreddin Hoca fikralarına A1, B1 ve C2 seviyelerinde yer verilmezken ders kitaplarında A2 seviyesinde 1 fikraya (s. 113, Mektup), B2 seviyesinde 1 fikraya (s. 49, Kazan Doğurdu), C1 seviyesinde ise 1 fikraya (s. 132, Hocanın Hesabı) yer verilmiş; çalışma kitaplarında B2 seviyesinde 1 fikraya (s. 50, Hindi) yer verilmiştir.

\section{Seviyelere Uygun Nasreddin Hoca Fikrası Teklifleri}

\section{A1 Fikrası}

\section{Ev Çok Karanlık}

Bir gün Nasreddin Hoca, evin içinde yüzüğünü yitirdi. Yüzüğü aradı ama yoktu. Evin önüne çıktı. Orada da aradı. Komşuları Hoca'yı gördü ve sordular:

Komşu: Hocam, orada ne arıyorsun?

Hoca: Yüzüğümü.

Komşu: Sen yüzüğü nerede kaybettin? 
Hoca: Evde.

Komşu: Evdeki yüzüğü niçin dişarıda arıyorsun?

Hoca: Ev çok karanlık (Güleç, 2012: 78-79).

\section{A2 Fikrası}

\section{Dünyanın Merkezi}

Nasreddin Hoca'nın arkadaşları bir gün ona sormuşlar:

- Hocam dünyanın merkezi neresidir?

Hoca:

- Ayağının altına bakmış. Burası dünyanın merkezidir.

Arkadaşları gülmüşler ve:

- Hocam nereden biliyorsun?

Hoca:

- Buyurun, ölçebilirsiniz (Koltaş, 2014: 13).

\section{B1 Fikrası}

\section{Sen de Haklısın}

Nasreddin Hoca kadı iken bir gün dostlarından biri evine gelmiş, bir komşusuna karşı açtığı bir davayı anlatarak:

- "Hoca! Ne dersin, haklı mıyım?” diye sormuş.

Hoca şöyle bir düşünüp:

- "Haklısın.” demiş.

Ertesi gün dostunun dava ettiği komşusu da Hoca’ya uğrayıp aynı davayı kendi açısından anlatarak:

- “Hoca! Ne dersin, haklı mıyım?” diye sormuş.

Hoca şöyle bir düşündükten sonra ona da:

- Haklısın, demiş.

Kocasının konuşmalarını kapı arasından dinleyen karısı, adam gittikten sonra:

- Hoca, dün davacı geldi, adama haklısın dedin. Bugün davalı geldi, ona da haklısın dedin. Hem davacı hem de davalı ikisi birden haklı olur mu?

Hoca şöyle bir düşündükten sonra cevap vermiş:

- Sen de haklısın hanım (Güleç, 2012: 23)!

\section{B2 Fikrası}

\section{Yorgan Gitti Kavga Bitti}

Gecenin bir yarısında Hoca'nın evinin önünde iki kişi kavgaya tutuşunca Hoca meraklanmış. Karısının itirazını dinlememiş, dışarı çıkmış. Üstüne de dışarıda üşümemek için yorganını almış.

Adamlara:

-"Yahu durun, neden kavga ediyorsunuz?" demeye firsat kalmadan biri Hoca'nın sırtındaki yorganı kaptığı gibi kaçmış. Öteki de başka bir yöne sıvışmış. Hoca eve eli boş dönmüş. Karısı sormuş:

- Hocam kavgayı ayırabildin mi?

Hoca: 
- Tabii ki hanım, demiş. Yorgan gitti, kavga bitti (Koltaş, 2014: 49)

\section{C1 Fıkrası}

\section{Ye Kürküm Ye}

Günlerden bir gün Hoca’yı yemeğe davet etmişler. Hoca davete, günlük kıyafetiyle katılmış. Katılmış ama ne hoş geldin ne sefa getirdin diyen var. Herkes, alı pullu kıyafetlilere el pençe divan duruyormuş. Bakmış olacak gibi değil Hoca, bir koşu evine gitmiş, sandıktaki işlemeli kürkünü giyip yemeğe geri dönmüş. Biraz önce hoş geldin demeyenler, önünde yerlere kadar eğilmişler. Hoca'yı, yere göğe sığdıramayıp başköşeye oturtmuşlar. Kuzunun en güzel yerini önüne koymuşlar. Herkes hocanın yemeğe başlamasını bekliyormuş. Hoca bir taraftan kürkünün kolunu sofrada sallamaya, bir taraftan da "Ye kürküm ye, ye kürküm ye!"” demeye başlamış.

-İlahi Hoca, demişler, kürkün yemek yediğini kim görmüş? Hoca taşı gediğine koymakta gecikmemiş:

-Eee, demiş Hoca, marifet kürkteymiş, kürksüz adamdan sayılmadık... İtibarı o gördü, yemeği de o yesin (Koltaş, 2014: 48)

\section{Tartışma ve Sonuç}

Türk kültürünün ders kitaplarındaki yeri ve fikraların kullanılması ile dil becerilerinin geliştirilerek kültür aktarımının sağlanması hususunda yapılan çalışmalara bakıldığında halk edebiyatından gelen kültür ürünlerinin ders kitaplarındaki yerinin yetersiz olduğu, fikralar yoluyla dil becerilerini geliştirmek üzere yapılacak çalışmaların daha faydalı olabileceği belirtilmiştir. Bunun yanında Nasreddin Hoca fikralarının dil unsurları bakımından zenginliği ve Türk kültürüne ait unsurları barındırma bakımından yabancı dil olarak Türkçe öğrenen öğrencilerin aktif söz varlığının ve yaratıcı düşünme becerilerinin geliştirilmesinde katkı sağlayabileceği ifade edilmiştir. Türk kültür unsurları yönünden zenginliği de kültür aktarımı sürecinde Nasreddin Hoca fikralarının kullanılabilir olduğunu göstermektedir (Akkaya, 2013; Baki ve Karakuş, 2014;Demirtaş, 2012; Doğru ve Kaplan, 2017; Karakaya, 2016; Şen, 2007;Tekşan, 2012; Temizkan, 2011;Ulutaş ve Kara, 2017;Yalçın, 2009).

Yapılan çalışmada Nasreddin Hoca fikralarının Türkiye'de yaygın olarak kullanılan yabancılara Türkçe öğretim setlerinde yer alıp almadığı, yer alanların hangi kur seviyelerinde bulundukları tespit edilmeye çalışılmıştır.

Araştırma sonucunda, Gazi TÖMER ve Hitit Türkçe öğretim setlerinde Nasreddin Hoca fikralarına hiç yer verilmediği görülmüş̧ür. İstanbul Türkçe öğretim setinde; A2, B2 ve C1 seviyelerinde toplam 7 fikra yer almaktadır.

Yunus Emre Enstitüsü tarafından hazırlanan Yedi İklim Türkçe öğretim setinde ise Nasreddin Hoca fikralarına, A1, B1 ve C2 seviyelerinde yer verilmezken, A2, B2 ve C1 seviyelerinde toplam 4 fikraya yer verilmiş̧tir.

Bu sonuçlara göre Yedi İklim Türkçe ve İstanbul setlerinin, Nasreddin Hoca fikralarının yabancılara tanıtılmasına ve bu vesileyle Türk kültürünün aktarımına katkı sağladığg söylenebilir.

Elde edilen bulgulardan hareketle Nasreddin Hoca fikralarının yabancı dil olarak Türkçe öğretim setlerinde sistemli bir şekilde kullanılmadığını ve Nasreddin Hoca fikralarına az sayıda yer verildiğini söylemek mümkündür. Yabancı dil olarak Türkçenin öğretiminin yeni bir alan olması ve bu sebeple ders kitaplarının tasarlanmasına yönelik yeterli çalışmanın yapılmamış olması elde edilen sonucun sebeplerinden biri olarak değerlendirilebilir. Nitekim elde edilen sonuçlar çalışmaya paralel olarak yapılmış ve literatür taraması ile ortaya konulmuş olan önceki çalışmalarla örtüşmektedir.

Nasreddin Hoca fikralarının yabancı dil olarak Türkçe öğretimi sürecinde daha fazla ve sistemli bir şekilde kendisine yer bulması fikraların dil yapıları bakımından zenginliği ve kültür unsurlarını yoğun olarak içinde barındırması bakımından yabancı dil olarak Türkçe öğrenen öğrencilerde hem dil becerilerinin gelişmesini hem de Türk kültürünü öğrenme süreçlerinin hızlanmasını temin edebilecektir. 
Bu sebeple çalı̧̧mada, Avrupa dil portfolyosunda belirtilen kur seviyeleri ve bu seviyelerin gerektirdiği dil bilgisi yapılarına uygun olarak düzenlenen örnek Nasreddin Hoca fikraları da teklif edilmiştir.

Çalışma sonuçlarından hareketle şu teklifleri yapmak mümkündür:

1. Dil öğretimi aynı zamanda kültür öğretimidir. Yabancılar için hazırlanan Türkçe öğretim setlerinde Türk kültürüne ağırlık verilmelidir.

2. Nasreddin Hoca fikraları, Türk kültür ve mizah anlayıșının temel unsurlarından biridir ve birçok milletin kültürünü etkilemiştir. Ortak kültür unsuru niteliğindeki Nasreddin Hoca fikralarına dil öğretiminin "bilinenden bilinmeyene doğru hareket edilmesi" ilkesini doğrultusunda yabancılara Türkçe öğretiminde yer verilmelidir.

3. Kurgularının basitliği ve dil yapılarının düzenlenebilir olması bakımından Nasreddin Hoca fikralarından her kur seviyesinde yararlanılmalıdır.

\section{Teşekkür ve Bilgilendirme}

Yapılan çalışma 30 Eylül - 2 Ekim 2016 tarihleri arasında Eskişehir'de düzenlenen Uluslararası Nasreddin Hoca Sempozyumunda sözlü bildiri olarak sunulmuştur. 


\section{References}

Akkaya, A. (2013). Yabancılara Türkçe Öğretimi Kapsamından Fıkralar: Nasreddin Hoca Fıkraları. Millı̂ Folklor Uluslararası Kültür Araştırmaları Dergisi, 25 (100), 171-181.

Aksan, D. (2007). Her Yönüyle Dil Ana Çizgileriyle Dilbilim. Ankara: Türk Dil Kurumu Yayınları.

Albayrak, N. (2006). Nasreddin Hoca. Türkiye Diyanet Vakfi İslâm Ansiklopedisi. İstanbul: Türkiye Diyanet Vakfı Yayın Matbaacılık ve Ticaret İşletmesi.

Baki, Y. Karakuş, N. (2014). Fıkra Türünün Eğitimdeki Yeri ve Türkçe Ders Kitaplarındaki Kullanılabilirliği. Tarih Okulu Dergisi (TOD), 7, 785-812. doi: http://dx. doi. org/10. 14225/Joh406

Demirtaş, T. (2012). Değerler eğitiminde edebî ürünlerden yararlanma: Nasreddin Hoca Fıkraları (Yüksek lisans tezi). Yükseköğretim Kurumu Başkanlığı Tez Merkezi’nden edinilmiştir. (328104).

Doğru, M. Kaplan, H. (2017). Yabancılara Türkçe Öğretiminde Türk Halkbilimi ve Türk Halk Edebiyatı Unsurlarının Kullanımı: İstanbul Türkçe Öğretim Seti Örneği. Tarihin Peşinde Uluslararası Tarih ve Sosyal Araştırmalar Dergisi, 17, 227-240.

Ergin, M. (2012). Türk Dil Bilgisi. İstanbul: Bayrak Basım/Yayım/Tanıtım.

Güleç, İ. (2012). Nasreddin Hoca'nın Biri Bir Gün. İstanbul: İz Yayıncılık.

Karakaya, S. (2007). Nasreddin Hoca Fıkralarının Eğitim Değeri ve Fıkraların Benlik Durumlarına Göre Değerlendirilmesi (Yüksek lisans tezi). Yükseköğretim Kurumu Başkanlığı Tez Merkezi’nden edinilmiştir. (210311).

Kıran, Z. Kıran, A. (2010). Dilbilime Giriş (Dilbilgisinden Dilbilime). Ankara: Seçkin Yayınc1lık.

Koltaş, E. (2014). Nasreddin Hoca'dan Fıkralar. İstanbul: D-Eğitim Kitaplığı.

Patton, M. Q. (2002). Qualitative Research\& Evaluation Methods (3 ${ }^{\text {rd }}$ ed.). Thousand Oaks, California: Sage Publications.

Pehlivan, F. (2007). Yabancı Dil Olarak Türkçe Öğretiminde Kültürlerarası Etkileşim Odakl Yaklaşım Uyarınca Metin Çalışmaları. (Yüksek Lisans Tezi) İstanbul Üniversitesi Sosyal Bilimler Enstitüsü.

Şen, Ü. (2016). İki Dilli Türk Çocuklarına Temel Beceri ve Temel Değerlerin Öğretiminde Nasrettin Hoca Fıkralarının Yeri. Mehmet Akif Ersoy Üniversitesi Eğitim Fakültesi Dergisi, 40, 257-272.

Tekin, T. Ölmez M. (2003). Türk Dilleri-Giriş-. İstanbul: Yıldız Dil ve Edebiyat Dizisi: 2.

Tecer, A. K. (1964). NasreddinHoca. MEB İslâm Ansiklopedisi (c. 9, ss. 109ª-114 ). İstanbul: MEB Devlet Kitapları İstanbul Basımevi.

Temizkan, M. (2011). Türkçe Öğretiminde Yaratıcı Düşünmeyi Geliştirme Bakımından Nasreddin Hoca Fıkraları. Mustafa Kemal Üniversitesi Sosyal Bilimler Enstitüsü Dergisi, 8 (16), 195-223.

Tuna, O. N. (1990). Sümer ve Türk Dillerinin Tarihi Ilgisi ile Türk Dilinin Yaşı Meselesi. Ankara: Atatürk Kültür, Dil ve Tarih Yüksek Kurumu Türk Dil Kurumu Yayınları.

Türkçe Sözlük (2011). Ankara: Türk Dil Kurumu Yayınları.

Ulutaş, M. Kara, M. (2017). Türkçe Ders Kitaplarında Nasreddin Hoca ve Fıkraları. Journal of World of Turks, 9 (3), 63-87.

Yıldırım, A. Şimşek, H. (2006). Sosyal Bilimlerde Nitel Araştırma Yöntemleri. Ankara: Seçkin yayınları.

Yin, R. K. (2003). Applications of Case Study Research Second Edition (Applied Social Research Methods Series Volume 34). California: Sage Publications.

\section{İncelenen Ö̆rretim Setleri:}

Yabancılar İçin Türkçe (A1, A2, B1, B2, C1) (2013). Gazi Üniversitesi Türkçe Öğrenim ve Araştırma Merkezi. Ankara. 
İstanbul Yabancılar İçin Türkçe (A1, A2, B1, B2, C1) (2014). Kültür Sanat Basımevi. İstanbul.

Yeni Hitit Yabancılar İçin Türkçe (1 Temel, 2 Orta, 3 Yüksek) (2016). Ankara Üniversitesi TÖMER. Ankara.

Yedi İklim Türkçe (A1, A2, B1, B2, C1, C2) (2015). Yunus Emre Enstitüsü. Ankara. 